\title{
MOTIVASI WISATAWAN TIMUR TENGAH BERWISATA KE PUNCAK CIANJUR
}

\author{
Taufiq Hidayat ${ }^{1}$ \\ Mahasiswa Program Studi Doktor Kajian Pariwisata \\ Dosen STIEPAR YAPARI Bandung \\ taufiqhi7912@gmail.com
}

\author{
Janianton Damanik ${ }^{2}$ \\ Dosen Program Studi Doktor Kajian Pariwisata \\ Sekolah Pascasarjana Universitas Gadjah Mada dan Program Studi Pembangunan \\ Universitas Gadjah Mada \\ antondmk@ugm.ac.id \\ John Soeprihanto ${ }^{3}$ \\ Dosen Program Studi Doktor Kajian Pariwisata \\ Sekolah Pascasarjana Universitas Gadjah Mada dan Program Studi Manajemen \\ Fakultas Ekonomi dan Bisnis Universitas Gadjah Mada \\ John.soeprihanto@gmail.com
}

\begin{abstract}
ABSTRAK
Motivasi merupakan dorongan mengapa wisatawan melakukan perjalanan, Puncak Cianjur merupakan fenomena yang menarik dimana destinasi ini banyak diminati oleh wisatawan Timur Tengah. Penelitian ini bertujuan untuk mendeskripsikan apa yang melatarbelakangi mereka berwisata ke Puncak Cianjur, faktor apa yang menarik dan mendorong mereka untuk berkunjung (push factor dan pull factor), secara khusus memfokuskan pada motivasi pelarian dari pasar wisatawan yang sedang berkembang ini dan memberikan saran untuk promosi pariwisata di Kabupaten Cianjur. Metode yang digunakan dalam penelitian ini adalah "studi kasus" dengan pendekatan yang digunakan dalam adalah pendekatan kualitatif perspektif emik, sementara teknik pengolahan data dilakukan dengan teknik wawancara, observasi, dan studi dokumentasi.

Hasil penelitian menunjukkan bahwa motivasi wisatawan Timur Tengah berwisata didasarkan pada motivasi fisik, personal, interpersonal, dan bersenangsenang. Yang menjadi push factor atau faktor pendorong adalah motivasi melarikan diri dan petualangan atau interaksi sosial. Sedangkan faktor penarik atau pull factor yang menjadi alasan mereka untuk melakukan perjalanan adalah udara sejuk, pemandangan yang indah, dan keramah tamahan serta mayoritas penduduknya. Terlepas dari atribut Puncak Cianjur yang dianggap dapat memfasilitasi pelarian mereka dan mampu memenuhi kebutuhan mereka di destinasi.
\end{abstract}


Kata Kunci : Motivasi, Wisatawan Timur Tengah, Puncak Cianjur.

\section{PENDAHULUAN}

Wisatawan Timur Tengah salah satu wisatawan mancanegara yang terus mengalami pertumbuhan, trendnya cenderung terus mengalami kenaikan dari 144 ribu wisatawan pada tahun 2012 meningkat menjadi 292 ribu wisatawan pada tahun 2016 (BPS, 2017). Kenaikan tersebut menurut ketua Asosiasi Travel Agent Indonesia (ASITA) Cabang Cianjur disebabkan oleh dua faktor yaitu: pertama, kondisi keamanan dan kenyamanan berwisata yang cenderung terus kondusif, dan kedua, semakin banyaknya pembukaan rute penerbangan langsung dari negaranegara Timur Tengah ke Indonesia.

Puncak merupakan destinasi yang paling banyak diminati oleh wisatawan manca negara asal Timur Tengah, data mutakhir tentang jumlah kunjungan wisatawan Timur Tengah khususnya ke Puncak Cianjur menurut Himpunan Pramuwisata Indonesia (HPI) Kabupaten Cianjur, lebih dari 200 ribu orang selama tahun 2016, (Kurniawan, 2017). Jumlah tersebut jika mengutip pernyataan mentri pariwisata Arif Yahya sebenarnya masih jauh dibandingkan dengan negara Thailand yang rata rata pertahun mencapai 600 ribu orang wisatawan asal Timur Tengah.

\section{Tabel 1 Kedatangan Wisatawan Timur tengah Menurut Kebangsaan Tahun 2016 vs 2015}

\begin{tabular}{|l|r|r|r|r|r|}
\hline \multirow{2}{*}{ Kebangsaan } & \multicolumn{2}{|c|}{2016} & \multicolumn{2}{c|}{2015} & \multirow{2}{*}{ \% Perubahan } \\
\cline { 2 - 5 } & Pengunjung & Persentase (\%) & Pengunjung & Persentase (\%) & \\
\hline $\begin{array}{l}\text { Saudi Timur } \\
\text { tengahia }\end{array}$ & 197.681 & 1,72 & 164.643 & 1,61 & 20,07 \\
\hline Bahrain & 2.243 & 0,02 & 1.685 & 0,02 & 33,12 \\
\hline Kuwait Emirat & 6.368 & 0,06 & 8.306 & 0,08 & $-23,33$ \\
\hline Mesir & 19.948 & 0,17 & 12.972 & 0,13 & 53,78 \\
\hline $\begin{array}{l}\text { Uni } \\
\text { Timur tengah }\end{array}$ & 9.016 & 0,08 & 10.315 & 0,10 & $-12,59$ \\
\hline Yaman & 9.478 & 0,08 & 8.715 & 0,09 & 8,76 \\
\hline Qatar & 1.856 & 0,02 & 1.595 & 0,02 & 16,36 \\
\hline Lainnya & 45.808 & 0,40 & 29.330 & 0,29 & 56,18 \\
\hline
\end{tabular}

Sumber: Badan Pusat Statistik, 2017

Badan Pusat Statistik pada tahun 2017 mencatat rata-rata kedatangan wisatawan Timur Tengah tumbuh mencapai $20 \%$ dengan jumlah kunjungan terbanyak berasal dari Arab Saudi, jika mengacu pada data jumlah kunjungan wisatawan menurut Himpunan Pramuwisata Indonesia (HPI) Kabupaten Cianjur artinya sebanyak $80 \%$ wisatawan Timur tengah melakukan kunjungan di daerah Puncak Cianjur.

Maraknya wisatawan Timur Tengah yang berwisata ke Puncak Cianjur sangat menarik untuk diteliti, motivasi apa yang melatarbelakangi mereka untuk 
berkunjung. Motivasi dipandang sebagai bagian dari sisi kebutuhan dan keinginan psikologis maupun biologis, yang meliputi bagian yang tidak dapat dipisahkan yang dapat mendorong dan menarik seseorang untuk berbuat atau melakukan aktivitas tertentu. Motivasi seseorang dipengaruhi oleh dua faktor yaitu faktor pendorong (push motivation) berhubungan dengan dorongan, perasaan, dan insting yang berasal dari dalam diri seseorang, faktor penarik (pull motivation) melibatkan representasi mental seperti pengetahuan atau keyakinan.

Motivasi pendorong dan penarik adalah faktor penting dalam memahami perilaku wisatawan, terutama dalam hal bagaimana mereka memilih destinasi untuk dikunjungi. Konsep (Crompton, 1979) menjelaskan kerangka push dan pull factor bahwa wisatawan melakukan perjalanan karena mereka didorong oleh kekuatan internal mereka dan ditarik oleh kekuatan eksternal dari destinasi. Sebagian besar faktor pendorong terkait dengan asal wisatawan dan mewakili keinginan internal para pelancong individu (Uysal dan Hagan, 1993), yang bersifat sosio-psikologis (Crompton, 1979). Contoh faktor pendorong atau push factor adalah keinginan untuk kebebasan, hubungan interpersonal, dan ikatan keluarga (Sung et al., 2016). Di sisi lain, pull factor terkait destinasi (Crompton, 1979) dan mewakili fitur nyata atau "objek" yang memotivasi individu untuk melakukan perjalanan ke destinasi (Dann, 1977).

Penelitian ini bertujuan untuk a) mengetahui motivasi wisatawan Timur Tengah berkunjung ke Puncak Cianjur; b) faktor apa yang menarik dan mendorong mereka untuk berkunjung (push factor dan pull factor).

\section{METODOLOGI}

Penelitian ini menggunakan metode "studi kasus" untuk mengungkap, memahami, dan menggambarkan realitas dan fenomena yang terjadi di lapangan. Desain penelitian yang digunakan bersifat deskriptif, yang bertujuan untuk menjelaskan, menggambarkan, atau melukiskan secara sistematis, faktual, dan akurat mengenai fakta yang diselidiki.

Studi kasus merupakan kajian penelitian kualitatif yang rinci dari suatu latar belakang peristiwa tertentu (Yin,2006). Studi kasus lebih memposisikan sebagai strategi penelitian, tetapi studi kasus juga dapat digunakan untuk meneliti individu dan kelompok komunitas tertentu (Idrus,2009) Studi kasus yang digunakan dalam penelitian ini bersifat tunggal yang menekankan pada pemahaman secara mendalam terhadap kasus yang sedang diteliti. Dimana tujuannya untuk memahami konstruk fenomena umum dari kasus yang bersangkutan (Idrus, 2009).

Pendekatan yang digunakan dalam penelitian ini ialah dengan pendekatan kualitatif perspektif emik, mengacu pada sudut pandang suatu masyarakat dalam mempelajari dan memberi makna terhadap satu tindakan, atau membedakan dua tindakan. pendekatan ini dipilih karena peneliti dalam hal ini memang menawarkan sesuatu yang lebih obyektif mengacu pada pandangan wisatawan yang dikaji.

Teknik pengumpulan data didapatkan melalui observasi, wawancara, dan studi dokumentasi. Teknik sampling yang digunakan oleh peneliti adalah 
purposive sampling. Purposive sampling merupakan teknik pengambilan sampel sumber data dengan beberapa pertimbangan, misalnya memilih partisipan yang dianggap bisa mewakili suatu kondisi yang diharapkan mampu memudahkan peneliti untuk menjelajahi objek atau situasi sosial yang diteliti secara mendalam. Total informan yang dijadikan sampel sebanyak lima orang semuanya warga negara Arab Saudi. Peneliti memutuskan kelima orang tersebut sebagai informan kunci yang dianggap paling sesuai dan tepat untuk mewakili suatu kondisi sosial yaitu wisatawan Timur Tengah yang memiliki ketertarikan berkunjung ke Puncak Cianjur.

\section{HASIL DAN PEMBAHASAN}

Dalam wawancara mendalam terhadap lima orang responden laki-laki, Semua responden berusia antara 25 samapai dengan 45 tahun. Sebagian besar responden memiliki gelar sarjana dan sudah bekerja. Terdapat empat kategori berbeda dari motivasi yang muncul selama wawancara, yaitu motivasi melarikan diri secara fisik, motivasi pribadi untuk melarikan diri, motivasi antar pribadi, dan motivasi bersenang senang. Semua hal tersebut akan disajikan dan dibahas di bawah ini.

\section{Motivasi Fisik}

\section{Cuaca}

Di beberapa negara Timur Tengah suhu udara pada saat musim panas seringkali mencapai 45-50 derajat Celcius. Selama musim panas antara bulan Juni hingga Agustus cuaca panas dikombinasikan dengan kelembaban tinggi telah memotivasi orang-orang Timur Tengah untuk pergi ke tempat yang memiliki iklim yang lebih ringan (Michael et al., 2011; Prayag dan Hosany, 2014). Udara sejuk di Puncak dan suhu yang relatif lebih rendah dibandingkan dengan di negara mereka, menjadi alasan bagi mereka termotivasi untuk melakukan perjalanan ke Puncak. Kelima informan menyatakan cuaca merupakan faktor utama motivasi yang menarik semua wisatawan Timur Tengah untuk melarikan diri ke Indonesia, seperti yang dijelaskan oleh Hattan,

"Begitu Anda memasuki musin panas di sini [di Arab Saudi] Anda hanya ingin melarikan diri ke suatu tempat dimana terdapat udara yang dingin ... jadi yang selalu ada di pikiran anda adalah Puncak".

Hal yang sama disampaikan oleh ibu Rini yang sudah lama bermukin di Arab Saudi mengatakan bahwa Puncak di kalangan masyarakat Arab Saudi sejauh pengetahuannya merupakan daerah dengan pemandangan yang hijau jauh berbeda dibandingkan dengan di negaranya. Karena pemandangan yang indah dan pegunungan hijau mereka sering menyebut Puncak dengan sebutan jabal aljannah atau gunung surga. Sebuah pemahaman yang sederhana menurut mereka terkait imajinasi surga yang direpresentasikan terhadap kawasan ini. 


\section{Pemandangan}

Wilayah "Timur Tengah" merupakan wilayah yang bersifat kering dan panas, tidak banyak binatang dan tumbuhan yang dapat tumbuh di daerah ini. Kebanyakan negara Timur Tengah berupa ekosistem gurun pasir, negara yang paling terkenal dengan gurun pasir atau padang pasirnya adalah Arab Saudi. Memang negara ini banyak sekali dijumpai gurun. Di bagian utara negara ini terdapat gurun An- Nafud yang memiliki luas sekitar $68.035 \mathrm{~km}^{2}$. Di sebelah selatan terdapat gurun Rub Al-Khali yang luasnya sekitar $593.110 \mathrm{~km}^{2}$. Bahkan diperkirakan sekitar $841.750 \mathrm{~km}^{2}$ kawasan Arab Saudi ditutupi oleh bukit-bukit pasir yang selalu berpindah- pindah mengikuti tiupan angin.

Uni Emirates Arab negara yang terkenal di Timur Tengah terletak di tepi Rub al-Khali (perempatan kosong), salah satu gurun terbesar di dunia. Negara ini memiliki lanskap datar dan tandus yang sering terkena badai pasir. Berbeda dengan Puncak Cianjur yang terdapat varietas pemandangan hijau, termasuk daerah perkebunan teh dan pegunungan hutan tropis. Puncak juga merupakan rumah bagi banyak spesies flora dan fauna yang unik yang berada di Taman Nasional Gunung Gede Pangrango (misalnya Jenis-jenis anggrek dan species paku pakuan, lutung surili) yang tidak dapat dilihat di tempat lain di dunia.

Hampir semua informan memberikan tanggapan ingin melarikan diri dari pemandangan gurun pasir dan melihat pemandangan alam yang hijau di Puncak, hutan tropis, hujan dan pegunungan, dan mengalami lingkungan yang tidak tercemar. Seperti yang disampaikan oleh Hattan:

"Saya pergi ke Puncak Cianjur karena di sana banyak pemandangan yang indah, tanaman hijau, alam, Pemandangan yang berbeda sama sekali. Kami punya pemandangan indah berupa gurun dan pantai, tapi sangat berbeda dengan di Puncak ketika Anda melihat tanaman hijau semacam itu, ini adalah pengalaman yang luar biasa".

Temuan studi ini konsisten dengan studi sebelumnya yang mengklaim bahwa cuaca / iklim dan lanskap adalah motivasi dan elemen perjalanan penting dalam pemilihan destinasi (Becken, 2010). Sebagai contoh, (Williams, 1998) mencatat bahwa iklim dan bentang alam adalah sama, jika tidak lebih, penting dari pada faktor lingkungan lainnya dalam memotivasi wisatawan untuk melarikan diri ke tempat lain selain milik mereka. Menurut (Fyhri, Jacobsen dan Tommervik, 2009), wisatawan lebih suka landskap yang subur dan bervegetasi dan mencari mengalami sesuatu yang kurang di lingkungan rumah mereka.

\section{Kegiatan Di Luar Ruangan}

Motivasi fisik bukan saja terkait dengan cuaca dan pemandangan tetapi ada pengaruhnya terhadap aktivitas mereka di luar ruangan, orang Timur Tengah merasa partisipasi mereka dalam kegiatan di luar rumah terbatas karena norma sosial-budaya dan praktik keagamaan yang ketat, termasuk aturan berpakaian. 
Sebagai contoh, menurut (Shallal, 2011), perempuan Emirat sangat terbatas dalam mobilitas dan kegiatan mereka karena sikap budaya konservatif.

Kegiatan di luar ruangan merupakan faktor penting yang memotivasi perjalanan wistawan Timur Tengah ke Puncak Cianjur. Ketika anda pergi tamasya anda dapat melakukan apa pun yang anda inginkan, seperti menyewa sepeda motor untuk keliling villa dengan kebut kebutan. Tidak ada yang bisa atau akan memberi tahu Anda apa yang harus dilakukan, tidak ada yang akan menangkap Anda dan memberitahu Anda untuk berhenti terhadap apa yang Anda lakukan, tidak seperti di sini [Arab Saudi] anda akan menemukan banyak keterbatasan.

Suara sepeda motor terdengar begitu keras ketika memasuki kawsan komplek villa mewah Kota Bunga. Suasana berbeda dapat kita temukan terlihat rombongan pemuda Timur Tengah menarik narik tuas gas sepeda motor sehingga minumbulkan suara yang sangat berisik, mereka berkendara beriringan sambil kebut kebutan. Wisatawan berusia muda lebih dominan di kawasan ini. Pemilik rental sepeda motor, bapak Deni, mengakui kendaraannya kerap disewa untuk hura-hura dan kebut kebutan. Ia memperoleh pendapatan dalam sehari sebesar satu juta, dengan bermodalkan tiga motor matik dan satu motor sport.

Liburan ke Puncak memungkinkan orang Timur Tengah untuk mengalami kebebasan melakukan apa yang mereka inginkan dan memfasilitasi partisipasi dalam kegiatan di luar ruangan. Temuan ini konsisten dengan ( $\mathrm{Wu}, \mathrm{Xu}$ dan Erdogan, 2009) yang mengklaim bahwa wisatawan bepergian untuk melakukan kegiatan di luar ruangan.

\section{Taman}

Kawasan Puncak yang meliputi wilayah Kabupaten Bogor dan Kabupaten Cianjur memiliki taman yang sangat terkenal, bagi wisatawan domestik mungkin sudah tidak asing terhadap Taman Safari Bogor. Taman Safari Cisarua Bogor merupakan salah satu tempat wisata favorit di kabupaten Bogor. Tidak seperti kebun binatang pada umumnya, dimana untuk bisa mengelilingi kebun binatang pengunjung harus berjalan kaki, di Taman Safari Indonesia pengunjung dapat berkeliling melihat dari dekat koleksi satwa dengan mengendarai mobil pribadi atau naik bis yang disediakan oleh pihak pengelola. Wisatawan juga bisa berinteraksi dan memberi makan secara langsung kepada hewan-hewan yang berjumlah sekitar 2500 koleksi satwa dari hampir seluruh penjuru dunia termasuk satwa langka, seperti harimau benggala, jerapah, singa, orang utan, gajah, anoa, komodo dan lain sebagainya.

Selain melihat binatang secara langsung dari dekat, wisatawan juga bisa mengajak teman atau keluarga untuk menikmati wahana lain yang tersedia seperti water park, cobow show dan lain sebagainya. Melihat koleksi satwa lalu dilanjutkan dengan menikmati beberapa wahana yang tersedia pasti akan menjadi memberikan pengalaman yang mengesankan dan tak terlupakan. Hal tersebut menerut pengakuan mereka yang menarik untuk berkunjung terutama mereka yang datang bersama keluarga, seperti yang dijelaskan oleh seorang driver guide, Rahmat: "Untuk tamu keluarga objek wisata yang paling sering dikunjungi berupa taman atau alam pegunungan," hal serupa juga dikatakan oleh driver guide yang 
lain, Yusuf :" Tempat wisata yang paling sering dikunjungi adalah wisata alam, Taman Cibodas dan Taman Safari merupakan tempat yang paling disukai oleh wisatawan".

Muhammad bin Abdul Karim, wisatawan asal Arab Saudi, langsung jatuh cinta pada Indonesia begitu menginjakkan kaki di kawasan Puncak. Tempat tersebut memanjakan dirinya dengan hamparan pegunungan hijau, udara segar. Suasana ini tak dia jumpai di negara asalnya. Karim datang ke Puncak untuk berbulan madu. Saudaranya memberi referensi mengenai Puncak, beberapa responden menyebutkan taman-taman di Puncak sangat menarik.

Temuan di atas mendukung klaim (McIntosh dan Goeldner, 1990) bahwa motivasi perjalanan fisik mencerminkan kebutuhan untuk berpartisipasi dalam kegiatan di luar ruangan. Orang-orang Timur Tengah didorong untuk melarikan diri dari lingkungan rumah mereka yang secara fisik tidak bersahabat dan ditarik oleh faktor lingkungan di Puncak Cianjur yang memiliki udara sejuk dan menyehatkan. Ini mendukung pendapat (Iso-Ahola, 1982) yang menyatakan bahwa melarikan diri mencari dikotomi dan menegaskan bahwa individu termotivasi untuk meninggalkan lingkungan rumah mereka dan pergi ke tempat lain, yang memenuhi kebutuhan mereka yang tidak terpenuhi.

\section{Motivasi Personal}

\section{Keluar dari rutinitas sehari hari}

Dalam kehidupan masyarakat moderen orang-orang cenderung dikontrol oleh aturan sehari hari dan tentu saja peraturan yang dibentuk oleh otoritas, lembaga, dan negara. Kegiatan rutinitas menyebabkan kebosanan dari pekerjaan atau hidup secara rutin menyebabkan orang-orang stres. Bersamaan dengan hal tersebut inilah saatnya orang menyadari bahwa mereka perlu melarikan diri dari lingkungan duniawi mereka.

Wisatawan Timur Tengah mengaku mereka pergi berlibur untuk melupakan rutinitas sehari-hari dan melarikan diri dari tekanan kerja dan stres. Misalnya, seperti apa yang disampaikan oleh Hattan :

"Berada dalam rutinitas kerja terkadang Anda benar-benar perlu istirahat dari semua pekerjaan dan liburan adalah cara yang ideal untuk keluar dari hal tersebut".

Informan yang lain mengatakan karena ini perjalanan kedua kalinya merasa dengan berwisata ke sini mereka akan merasakan suasan relaksasi dari aktifitas yang akan dilakukan sehari hari, selain mendapatkan relaksasi aktifitas berbelanja merupakan langkah untuk melupakan dari aktifitas sehari hari.

Menurut (Krippendorf, 1987), pilihan perjalanan seseorang dibentuk oleh masyarakat kehususan mereka dan kehidupan sehari-hari. Seringkali orang ingin melarikan diri dari masalah dunia mereka dan kegagalan pribadi mereka, dan mencari upaya untuk istirahat dan relaksasi, mengisi ulang dan memperbarui (Assiouras et al., 2015) (Li et al., 2016). Demikian juga halnya, menurut (Goodall,1988), pariwisata menawarkan peluang untuk melarikan diri dari pekerjaan dan pekerjaan sehari-hari (McCabe, 2009) dan meredakan ketegangan 
fisik dan mental melalui istirahat dan relaksasi di lingkungan baru (Van Vuuren dan Slabbert, 2011). Tampaknya lingkungan di Puncak Cianjur dapat membebaskan diri dari stres, orang-orang Timur tengah bisa melupakan tanggung jawab sehari-hari, bersantai dan merasa diperbaharui secara fisik dan mental.

\section{Waktu Luang}

Dalam pariwisata waktu luang sering disebut dengan istilah "leisure", "rekreasi", dan "bermain", banyak digunakan untuk merujuk pada kegiatan di luar pekerjaan. "Rekreasi" memiliki akar dalam bahasa Latin "Rekratio" yang berarti "mengembalikan ke kondisi fisik yang baik atau normal dari keadaan lemah atau lelah; berinvestasi dengan semangat atau kekuatan baru (Kaplan, 1960).

Rekreasi dilihat sebagai waktu luang di mana orang memiliki kebebasan untuk melakukan apa yang mereka inginkan. Hal tersebut bisa berarti kegiatan yang diikuti orang tanpa kekuatan atau kebutuhan. Waktu luang juga menandakan ketenangan atau kebebasan dari kontrol. Seperti yang dikemukakan oleh (Kelly,1994) bahwa waktu luang sebagai alternatif yang berkaitan dengan berbagai aspek lebih dari sekedar waktu. Aspek tersebut mencakup hampir setiap komponen dalam kehidupan, misalnya, pekerjaan, keluarga, pendidikan, perkembangan pribadi, dan seksualitas.

Oleh karena itu, rekreasi dan pariwisata adalah jalan keluar dari rutinitas sehari-hari. Bepergian untuk kegiatan seksual salah satunya dapat dianggap sebagai semacam kegiatan rekreasi yang dilakukan oleh beberapa wisatawan. Wisatawan yang merasa bosan dengan kehidupan sehari-hari mereka, pekerjaan dan tugas mereka telah menjadi penghalang perasaan gembira dalam hidup. Rutinitas sehari-hari menciptakan keinginan orang untuk keluar dan berpartisipasi dalam kegiatan lain tak terkecuali urusan seks.

Melarikan diri dari rutinitas sehari-hari yang membosankan merupakan salah satu faktor motivasi untuk melakukan perjalanan. Seperti yang dikatakan oleh salah seorang wisatawan asal Arab Saudi yang tidak bersedia disebutkan namanya mengatakan bahwa kehidupan seksual cukup aktif di sini, tetapi sudah diatur dan terlihat sangat berbeda dari negara lain. Sebagian besar tindakan terjadi di balik pintu yang tertutup rapat, dan tidak dibicarakan di depan umum oleh salah satu pihak yang terlibat. Tidak ada interaksi publik yang mungkin mengindikasikan hubungan pribadi apa pun.

Informan lain mengatakan bahwa seks adalah bagian dari masyarakat seperti di dunia pada umumnya. Ada banyak rumah bordil rahasia beroprasi di kota-kota Saudi. Ada banyak kasus yang mengeksploitasi pembantu rumah tangga untuk seks. Faktor lain adalah poligami yang populer di Timur Tengah. Tapi hanya beberapa orang kaya dan yang memiliki keistimewaan yang mampu memiliki banyak istri, pernikahan adalah urusan yang mahal bagi pria Saudi. Banyak pria Saudi menikahi orang asing sebagai akibat dari ini”.

Berdasarkan (Mannell dan Iso-Ahola, 1987), tampak bahwa orang cenderung berperilaku berbeda ketika mereka bepergian atau memilih untuk terlibat dalam kegiatan yang hampir berlawanan dengan apa yang mereka lakukan di lingkungan rumah mereka atau apa yang mereka alami sehari-hari. Waktu 
luang tampaknya terut berperan mendorong wisatawan untuk melakukan perjalanan dan melakukan kegiatan diluar kebiasaaan wisatawan.

\section{Motivasi Interpersonal}

\section{Keluarga}

Secara tradisi orang-orang Timur Tengah sangat termotivasi oleh kebersamaan keluarga; mereka selalu bepergian dengan anggota keluarga dan kerabat. Lingkaran sosial orang Timur Tengah cenderung tidak menyertakan rekan kerja atau tetangga saat berlibur, baik di rumah maupun di luar lingkungan rumah. Orang Timur Tengah memandang Indonesia sebagai destinasi ramah keluarga yang sangat memenuhi kebutuhan mereka akan ikatan keluarga. Bepergian ke Indonesia sangat menyenangkan karena menyatukan semua anggota keluarga. Temuan ini didukung oleh penelitian sebelumnya (Kim et al., 2003; McCabe, 2009; Mohammad dan Som, 2010; Yoon dan Uysal, 2005).

Indonesia atau Puncak juga memberikan kesempatan besar kepada wisatawan Timur tengah untuk terlibat dalam kegiatan yang ramah keluarga. Seperti yang dikatakan Amer:

"Puncak sangat cocok untuk berlibur bersama keluarga, beragam daya tarik wisata dan dapat memenuhi kepuasan sanak famili terutama istri untuk berbelanja dan anak saya bermain di taman karena di Puncak tamannya indah-indah memiliki kualitas barang yang baik dan harga yang terjangkau untuk berbelanja".

Bagi mereka salah satu alasan utama untuk bepergian ke Indonesia adalah kesempatan untuk menghabiskan waktu berkualitas bersama keluarga dan kerabat. Secara umum Indonesia dan Puncak khususnya telah memenuhi kebutuhan mereka untuk kegiatan keluarga karena menawarkan berbagai tempat untuk dikunjungi, hal-hal yang dapat dilakukan, dan kegiatan yang harus dilakukan ketika bepergian dengan keluarga. Mereka dan keluarga dapat pergi ke berbagai tempat wisata, mengunjungi taman hiburan, mendapatkan pengalaman hutan tropis dan membawa anak-anak mereka ke kebun binatang untuk melihat satwa liar, atau pergi ke pusat perbelanjaan.

\section{Interaksi Dengan Penduduk Lokal}

Orang Timur Tengah menempatkan banyak tekanan pada perilaku yang dapat diterima secara sosial. Secara individu mereka terikat oleh norma-norma agama, budaya mandat keluarga yang ketat. Interaksi mereka sangat terbatas oleh karena itu ketika berwisata mereka berusaha untuk melarikan diri dari norma sosial-budaya. Mereka lebih memilih berwisata ke Puncak Cianjur karena beberapa alasan utama yaitu karena keramah tamahan masyarakat yang dirasakan selama di Puncak Cianjur, serta mayoritas penduduknya yang beragama Islam.

Keramahan tamahan masyarakat setempat adalah faktor penarik motivasi lainnya. Menurut Hattan, "Orang Indonesia ramah dan rendah hati." Tampaknya keramahan dan sikap masyarakat setempat menarik wisatawan Timur Tengah 
untuk datang ke Puncak. Tidak sedikit yang menganggap masyarakat setempat sebagai kerabat, kerabat yang dimaksud adalah beberapa pengelola villa, dan masyarakat lokal lainnya yang di anggap oleh informan memberikan pelayanan yang baik dan membantu kebutuhan informan selama berada di Puncak Cianjur.

Menurut (Crompton, 1979), kesenangan saat berlibur mungkin lebih berorientasi pada orang dari pada berorientasi pada suatu tempat. Wisatawan yang melakukan liburan yang berorientasi pada orang sering kali melarikan diri dari dunia interpersonal mereka yang terdiri dari rekan kerja, anggota keluarga, kerabat, teman, dan tetangga untuk mendapatkan penghargaan yang lebih bervariasi dan meningkatkan interaksi sosial (Iso-Ahola, 1982) dengan penduduk setempat yang ramah dan sesama wisatawan di tempat yang baru (Iso-Ahola, 1982).

Interaksi mereka dengan warga negara Timur Tengah yang lain menunjukkan bahwa mereka terlihat cukup intim melakukan kontak sosial, pada saat yang sama mereka mencari kontak dengan orang-orang lokal yang ramah. Satu elemen yang sangat terpelihara dari lingkungan rumah mereka adalah berada dan menghabiskan waktu berkualitas bersama keluarga.

Tiga kategori motivasi ( fisik, personal, dan interpersonal) yang muncul selama wawancara mengkonfirmasi temuan penelitian sebelumnya yang menunjukkan bahwa alasan cuaca, melihat pemandangan indah, melakukan kegiatan luar ruangan, menikmati taman yang luas, melupakan tentang tanggung jawab sehari-hari yang memotivasi wisatawan untuk melakukan perjalanan ke destinasi, (Hadi, A.P, 2018; Prayag dan Hosany, 2014; Royo -Vela, 2009).

\section{Motivasi Bersenang-Senang}

Motivasi bersenang-senang termasuk melarikan diri dari lingkungan sehari-hari yang monoton dan kewajiban sosial-budaya kepada alternatif dunia lain, merasa santai, menghabiskan waktu bersama keluarga, dan bertemu penduduk setempat yang ramah (lihat Becken, 2010; Klenosky, 2002; Li dkk., 2016; Park dan Yoon (Dann 1977) hal tersebut memungkinkan wisatawan Timur Tengah untuk berperilaku yang tidak pantas, tidak seharusnya di lingkungan mereka. Di Puncak Cianjur, mereka dapat hidup bebas di lingkungan yang tidak terlalu rumit, suatu tempat dimana mereka dapat melakukan apa pun yang mereka suka dengan didukung oleh fasilitas akomodasi yang baik, amenitas, serta pelayanan yang sangat memuaskan.

\section{Kencan Dengan Wanita Lokal}

Seperti telah disebutkan sebelumnya, bahwa teori kepribadian Maslow telah diterima secara luas sebagai salah satu teori paling terkenal untuk menjelaskan motivasi manusia. Teori kepribadian Maslow mengidentifikasi lima tahap atau hierarki kebutuhan manusia yaitu kebutuhan fisiologis, kebutuhan akan rasa aman, kebutuhan akan rasa memiliki dan kasih sayang, kebutuhan akan penghargaan dan kebutuhan akan aktualisasi diri. Pada tahap ketiga, rasa memiliki telah menjadi elemen yang berkontribusi pada alasan mengapa orang melakukan perjalanan. Ketika orang merasa mereka kehilangan koneksi dan kelembutan dengan manusia lain dalam masyarakat mereka sendiri yang disebabkan oleh 
peraturan, menyebabkan mereka bersemangat untuk menemukan pengalaman otentik terutama di luar lingkungan mereka sendiri.

Selain keaslian keindahan tempat yang dikunjungi, banyak wisatawan juga mencari hubungan sejati, persahabatan, atau bahkan seks. Modernisasi dan gaya hidup telah mengikis cara hidup tradisional. Di dunia Timur Tengah saat ini, satusatunya konteks yang diterima secara luas dan diakui secara sosial untuk seks adalah pernikahan yang sah secara agama, disetujui keluarga, dan terdaftar oleh negara. Hal sealin itu dianggap 'ayb (memalukan), tidak senonoh, haram (terlarang) (Feki, 2013).

Di kawasan Puncak sempat terkenal dengan praktik kawin kontrak dan prostitusi berkedok wisata, di negara Timur Tengah kawin kontrak sudah biasa terjadi terlepas dari ajaran agama yang memperbolehkan laki-laki untuk memiliki istri lebih dari satu, cara ini merupakan cara yang paling mudah dan murah. Waktu layanan dapat berkisar dari satu jam hingga hampir satu bulan. Layanan santai ini dan lamanya waktu memungkinkan untuk keterlibatan emosional dan karenanya memberikan rasa "hubungan nyata" bagi wisatawan.

Di Puncak Cianjur wanita yang melayani pria Timur Tengah atau warga sekitar menyebutnya dengan istilah "jablay" menyediakan bentuk lain dari suatu pekerjaan, tidak hanya layanan seksual. Mereka membawa wisatawan Timur Tengah keliling jalan-jalan, makan siang atau makan malam (tentu saja, wisatawan Timur Tengah yang mentraktir). Aspek yang paling penting adalah mereka memberikan pertemanan dan "cinta" bagi wisatawan. Transaksi lebih santai, dan waktu tidak selalu menjadi masalah. Terlebih lagi, meskipun uang penting bagi mereka, para jablay cenderung melayani luar biasa untuk sejumlah uang yang mereka terima dari wisatawan. Hal ini juga dapat membentuk "keaslian" dari hubungan yang dirasakan oleh wisatawan.

\section{Cara Berpakaian}

Perjalanan ke Indonesia merupakan bentuk menentang cara berpakaian tradisional rata-rata negara Timur Tengah yang dibentuk dan dipandu oleh ajaran agama Islam dan iklim setempat, dan merupakan simbol identitas nasional. Di Indonesia, orang-orang Timur Tengah bisa bebas dari aturan berpakaian yang dibatasi dan bebas untuk mengenakan pakaian yang mereka sukai.

Wisatawan Timur Tengah yang diwawancarai menganggap mengenakan pakaian kasual sebagai hal yang menyenangkan. Di lingkungan negara mereka, laki laki mengganakan pakaian gamis, dan wanita mengenakan abhaya dan shaila yang membatasi mereka untuk berpartisipasi dalam kegiatan rekreasi (Shakona et al., 2015). Seperti yang disampaikan oleh Hattan : "Ketika berlibur di Puncak kami mengenakan pakaian Barat, di Arab Saudi berpakain sangat terbatas dan ini menyenangkan".

Mengenakan pakaian kasual di dunia alternatif atau fantasi (Dann, 1977) memungkinkan orang-orang Timur tengah untuk merasakan kebebasan dan melarikan diri dari kehidupan sosial dan budaya mereka. Temuan di atas sesuai dengan klaim Crompton (1979) bahwa liburan menawarkan kebebasan dari kebiasaan, nilai-nilai, dan harapan kelompok. 


\section{Keluar Dari Kebiasaan}

Ketika di destinasi sebagian orang-orang Timur Tengah nampak terlihat seperti menentang batasan aturan agama mereka. Beberapa responden mengaku terlibat dalam meminum-minuman yang haram (dilarang) dalam Islam. Meskipun keluarga mereka memberikan pengaruh besar pada anggota keluarga mereka untuk makanan apa yang bisa mereka makan (halal) dan tidak bisa makan (haram) di rumah, mereka tetap menentang agama mereka dengan minum alkohol, yang juga dianggap menyenangkan. Wisatawan yang tidak bersedia disebutkan namanya mengatakan :

"ya orang tuaku, mereka merasa tetap pada apa yang mereka ketahui; bagi saya tidak, saya akan pergi dan mencoba hal-hal yang berbeda ... bagi saya itu tidak masalah jadi kami bahkan mencoba."

Temuan penelitian ini konsisten dengan argumen bahwa liburan memberikan kesempatan kepada individu untuk keluar dari pembatasan domestik (McCabe, 2009). Menurut penelitian sebelumnya, wisatawan Muslim/Timur Tengah berharap akan diberikan banyak aspek dari lingkungan rumah mereka ketika berlibur (misalnya, fasilitas ramah Muslim, makanan halal, kamar dan fasilitas terpisah untuk wanita dan pria) (Battour, et al., 2012; Muhamad-Yunus et al., 2015; Nassar et al., 2015). Namun, orang-orang Timur Tengah yang berpartisipasi dalam penelitian ini mencari destinasi liburan yang memungkinkan mereka untuk menghindari aspek-aspek spesifik dari lingkungan negara mereka dan melarikan diri ke destinasi liburan untuk menikmati kegiatan dan pengalaman yang tidak diperbolehkan di negara mereka.

\section{SIMPULAN}

Studi ini menunjukkan bahwa motivasi wisatawan Timur Tengah berwisata didasarkan pada motivasi fisik, personal, interpersonal, dan bersenangsenang. Yang menjadi push factor atau faktor pendorong adalah motivasi melarikan diri dan petualangan atau interaksi sosial. Bagi mereka berwisata ke Puncak Cianjur akan merasakan relaksasi keluar dari rutinitas sehari hari, menikmati waktu luang dengan berinteraksi bersama penduduk lokal, dan meningkatan keintiman dalam keluarga. Mereka menganggap Puncak Cianjur merupakan tempat yang baik untuk wisata bersama keluarga.

Sedangkan faktor penarik atau pull factor yang menjadi alasan mereka untuk melakukan perjalanan wisata ke Puncak Cianjur adalah udara sejuk, pemandangan yang indah, dan keramah tamahan serta mayoritas penduduknya yang beragama Islam membuat mereka merasa nyaman dan tenang untuk berada di Puncak Cianjur. Selain itu di Puncak Cianjur terdapat tempat yang menarik untuk aktivitas bersama keluarga, serta kesempatan untuk dapat berkencan dengan wanita setempat merupakan pengalaman yang menarik. Penduduk yang ramah, fasilitas akomodasi yang baik, amenitas dan pelayanan yang sangat memuaskan, 
serta jaminan memperoleh kebebasan sehingga Puncak Cianjur merupakan tempat yang sangat baik untuk dikunjungi.

Motivasi pendorongan dan penarik ini saling berhubungan dan mereka terlibat dalam kedua motivasi secara bersamaan. Misalnya, mereka bepergian ke Puncak Cianjur untuk menjalin hubungan yang lebih berkualitas dengan keluarga dan teman di sisi lain mereka mereka menjalin keintiman dengan wanita lokal. Hubungan antara dorongan dan tarikan motivasi tidak lebih dari akal sehat, keputusan orang-orang Timur Tengah untuk melarikan diri sangat terkait dengan atribut khusus Puncak dan kemampuan mereka untuk menciptakan pengalaman baru yang tidak dapat mereka peroleh di negaranya.

\section{DAFTAR PUSTAKA}

Abodeeb, J. A. (2014). Destination image from an Timur tengah perspective: the influence of culture on perceptions of and motivations for visiting the Gold Coast. Thesis, Southern Cross University: Australia.

Assiouras, I., Skourtis, G., Koniordos, M., and Giannopoulos, A. (2015). "Segmenting East Asian Tourists to Greece by Travel Motivation", Asia Pacific Journal of Tourism Research, Vol. 20 No. 12, pp. 1389-1410.

Battour, M., Battor, M. and Ismail, M. (2012). "The mediating role of tourist satisfaction: A study of Muslim tourists in Malaysia”, Journal of Travel and Tourism Marketing, Vol. 29 No. 3, pp. 279-297.

Becken, S. (2010). The importance of climate and weather for tourism. Land Environment and People (LEaP), available at: www.lincoln.ac.nz/PageFiles/6750/WeatherLitReview.pdf (accessed18 Aug 2015).

Crompton, J. L. (1979). An assessment of the image of Mexico as a vacation destination and the influence of geographical location upon that image. Journal of travel research, 17(4), 18-23.

Dann, G. (1977). Anomie, ego-enhancement and tourism. Annals of Tourism Research, Vol. 4 No.4, pp. 184-194.

Dolnicar, S. (2015). Environmentally sustainable tourists, in Hall, C., Gossling, S. and Scott, D. (Ed.), Routledge Handbook of Tourism and Sustainability, Routledge, Abingdon, Oxon, United Kingdom, pp. 140-150.

Feki, S. (2013). Seks dan Hijab : Gairah dan Intimitas di Dunia Timur tengah yang Berubah. Jakarta : PT. Pustaka Alvabet.

Fodness, D. (1994). Measuring tourist motivation. Annals of Tourism Research, Vol. 21 No.3, pp. 555-581. 
Fyhri, A. Jacobsen, J. and Tømmervik, H. (2009). Tourists' landscape perceptions and preferences in a Scandinavian coastal region. Landscape and Urban Planning, Vol. 91 No. 4, pp. 202-211.

Gnoth, J, (1997). Tourism motivation and expectation formation. Annals of Tourism Research, Vol. 24 No.2, pp. 283-304.

Goodall, B. (1988). How tourists choose their holidays: An analytical framework", in Goodall, B. and Ashworth, G. (eds) Marketing in the Tourism Industry: The Promotion of Destination Regions, Routledge, London, pp. 1-17.

Hadi, A. P. (2018). Pola Perjalanan Wisatawan Timur Tengah Berdasarkan Profil Wisatawan Dan Motivasi Pola Pergerakan Di Bandung. In National Conference of Creative Industry.

Hancock, et al. (2009). An Introduction for Qualitative Research. National Institute for Health Research.

Howard, John A. and Seth, Jagdisth N., (1969). The Theory of Buyer Behavior. New York: JohnWilley \& Sonds, Inc.

Idrus, M. (2009). Metode penelitian Ilmu Sosial. Yogyakarta: PT. Gelora Akasara Pratama.

Iso-Ahola, S. (1982). Toward a social psychological theory of tourism motivation: A rejoinder. Annals of Tourism Research, Vol. 9 No. 2, pp. 256-262.

Kim, S., Lee, C. and Klenosky, D. (2003). The influence of push and pull factors at Korean national parks. Tourism Management, Vol. 24 No. 2, pp. 169180.

Klenosky, D. (2002). The "pull" of tourism destinations: A means-end investigation. Journal of Travel Research, Vol. 40 No. 4, pp. 396-403.

Krippendorf, J. (1987). The Holiday Makers: Understanding the Impact of Leisure and Travel. Butterworth-Heinemann, Oxford.

Li, M. Zhang, H. and Cai, L. (2016). A subcultural analysis of Tourism Motivations. Journal of Hospitality \& Tourism Research, Vol. 40 No. 1, pp. 85-113.

Maslow, A. (1954). Motivation and Personality. 1st ed., Harper, New York.

McCabe, S. (2009). Who needs a holiday? Evaluating social tourism. Annals of Tourism Research, Vol. 36 No. 4, pp. 667-688. 
McIntosh, W. and Goeldner, C. (1990). Tourism: Principles, Practices, Philosophies. 6th ed., Wiley, New York.

McKercher, B. (1993). Some fundamental truths about tourism: Understanding tourism's social and environmental impacts. Journal of Sustainable Tourism, Vol. 1 No. 1, pp. 6-16.

Michael, N., Wien, C., \& Reisinger, Y. (2017). Push and pull escape travel motivations of Emirati nationals to Australia. International Journal of Culture, Tourism and Hospitality Research, 11(3), 274-296.

Michael, I., Armstrong, A., Badran, B. and King, B. (2011). Dubai outbound tourism: An exploratory study of Emiratis and expatriates. Journal of Vacation Marketing, Vol. 17 No. 1, pp. 83-91.

Miles, M.B. \& A.M. Huberman. (1994). Qualitative Data Analysis. California: SAGE Publications Inc.

Mohammad, B. and Som, A. (2010). An analysis of push and pull travel motivations of foreign tourists to Jordan. International Journal of Business and Management, Vol. 5 No. 12, pp. 41-50.

Moleong, Lexy. J. 2004. Metode Penelitian Kualitatif. Remaja Rosdakarya. Bandung.

Muhamad-Yunus, N., Abd-Razak, N. and Ghani, N. (2015). Consumer purchase Intention towards Sharia Complaint Hotel $(\mathrm{SCH})$. Theory and Practice in Hospitality and Tourism Research, pp. 155-159.

Nassar, M., Moustafa, M. and Reisinger, Y. (2015). Factors influencing travel to Islamic destinations: An empirical analysis of Kuwaiti nationals. International Journal of Culture, Tourism and Hospitality Research, Vol. 9 No. 1, pp. 36-53.

Pearce, P. (1982). The Social Psychology Of Tourist Behaviour. 1st ed., Pergamon Press, New York.

Pearce, P., and Lee, U. (2005). "Developing the travel career approach to tourist motivation", Journal of Travel Research, Vol. 43 No. 3, pp. 226-237.

Pearce, P., Morrison, A. and Rutledge, J. (1998). In Tourism: Bridges Across Continents. McGraw-Hill, Sydney.

Plog, S. (1972). Why destination areas rise and fall in popularity. The Travel Research Association, Southern California Chapter, Los Angeles. 
Plog, S. (1974). Why destination areas rise and fall in popularity. Cornell Hotel and Restaurant Administration Quarterly Vol. 14 No.4, pp. 55-58.

Plog, S. (1991). Leisure Travel: Making it a Growth Market...Again! Wiley, New York.

Plog, S. (2001). "Why destination areas rise and fall in popularity: An update of a Cornell Quarterly classic", The Cornell Hotel and Restaurant Administration Quarterly Vol. 42 No. 3, pp. 13-24.

Prayag, G., Hosany, S., Muskat, B., \& Del Chiappa, G. (2017). Understanding the relationships between tourists' emotional experiences, perceived overall image, satisfaction, and intention to recommend. Journal of Travel Research, 56(1), 41-54.

Royo-Vela, M. (2009). "Rural-cultural excursion conceptualization: a local tourism marketing management model based on tourist destination image measurement', Tourism Management, Vol. 30 No. 3, pp. 419-28.

Sekaran, Uma. (2003). Research Methods for Business: A Skill-Building Approach 4th Edition. John Wiley \& Sons, Limited. Academic Internet Publishers Incorporated.

Shallal, M. (2011). Job satisfaction among women in the United Timur tengah Emirates. The Journal of International Women's Studies, Vol. 12 No. 3, pp. 114-134.

Sugiyono. (2014). Memahami Penelitian Kualitatif Alfabeta. Bandung: Alfabeta

Sung, Y. K., Chang, K. C., and Sung, Y. F. (2015). Market Segmentation of International Tourists Based on Motivation to Travel: A Case Study of Taiwan", Asia Pacific Journal of Tourism Research, Vol. 1 No. 21, pp. 862-882.

Taylor, G. (1974). Tourism Research. In Indicators of Change in the Recreation Environment A National Research Symposium. Betty vander Smissen, ed. Pennsylvania State University.

Uysal, M. and Hagan, L. (1993). Motivation of pleasure travel and tourism”, in Khan, M., Olsen, M., Var, T. (Eds), Encyclopaedia of Hospitality and Tourism, New York, pp. 798-810.

Van Vuuren, C. and Slabbert, E. (2011). Travel behaviour of tourists to a South African resort. African Journal for Physical Health Education, Recreation and Dance: Special Issue Vol. 1 No. 17, pp. 694-707. 
Williams, S. (1998). Tourism Geography. Routledge, London.

Willis, C. (2012). Attitudes and perceptions toward sex tourism in Las Vegas (MA thesis) Las Vegas. NV: University of Nevada.

$\mathrm{Wu}$, J., Xu, J. and Erdogan, E. (2009). "Investigating the Push and Pull Motivation of Visiting Domestic Destinations in China: A Means- End Approach: Means- end", Journal of China Tourism Research, Vol. 5 No. 3, pp. 287-315.

Yin, R. K. (2006). Case study methods. Handbook of complementary methods in education research, 3, 111-122.

Yoon, Y. and Uysal, M. (2005). "An examination of the effects of motivation and satisfaction on destination loyalty: A structural model", Tourism Management Vol. 26 No. 1, pp. 45-56.

\section{Internet}

Travel plus Indonesia. Diakses 13 Februari 2017. Dari https://travelplusindonesia.blogspot.co.id/2017/02/mengeksplor-puncakcianjur-destinasi.html.

Badan Pusat Statistik. Diakses $6 \quad$ Februari 2019 Dari https://www.bps.go.id/statictable/2014/09/08/1394/wisatawanmancanegara-yang-datang-ke-indonesia-menurut-kebangsaan-20002017.html

$\begin{array}{lllll}\text { Liputan6.com. } & \text { Diakses } & 6 & \text { Februari } & \text { 2019. Dari }\end{array}$ https://www.liputan6.com/bisnis/read/2933608/jurus-menpar-tarik-lebihbanyak-turis-timur-tengah-ke-ri 